\title{
Duszpasterstwo małżeństw i rodzin w pasterskiej posłudze Jerzego Ablewicza biskupa tarnowskiego (1962-1990)
}

Wstęp

Pewien etap swej pracy naukowej, poświęcony zagadnieniom małżeństwa i rodziny, ks. prof. Jerzy Bajda, kapłan diecezji tarnowskiej, odbywał wówczas, kiedy ster Kościoła tarnowskiego spoczywał w dłoniach bpa Jerzego Ablewicza (1962-1990). Refleksja nad osobą i nauczaniem ks. Bajdy pozwala stwierdzić, iż jego nauczanie wpisywało się w styl duszpasterzowania, jakim naznaczył ówczesny Kościół tarnowski bp Jerzy Ablewicz.

Pierwszą bowiem osobą odpowiedzialną za duszpasterstwo rodzin w diecezji - jak pisał Jan Paweł II adhortacji apostolskiej Familiaris consortio - jest biskup. Jako ojciec i pasterz winien szczególnie troszczyć się o tę dziedzinę duszpasterstwa, bez wątpienia pierwszoplano-
- Wstęp

- Formy i działania podejmowane na rzecz małżeństw i rodzin - Nauczanie pasterskie o małżeństwie i rodzinie - Zakończenie 
wą. Musi poświęcić jej swe zainteresowanie, troskę i czas, zapewnić jej ludzi i środki; nade wszystko jednak winien okazywać osobiste wsparcie rodzinom i tym wszystkim, którzy w różnych strukturach diecezjalnych pomagają mu w duszpasterstwie ${ }^{1}$.

Te słowa papieża Jana Pawła II wskazują na wyjątkową rolę, jaką winno odgrywać w posłudze pasterskiej każdego biskupa duszpasterstwo małżeństw i rodzin. Jednym z pasterzy, wypełniających z wielkim zapałem to zadanie, był biskup tarnowski Jerzy Ablewicz. Biskup ten - świadomy swej pasterskiej odpowiedzialności, poprzez swoją wiedzę i gorliwość apostolską - wycisnął charakterystyczne znamię na obliczu chrześcijańskiej rodziny w Kościele tarnowskim w drugiej połowie XX wieku.

Troska biskupa Ablewicza o chrześcijański kształt małżeństw i rodzin $\mathrm{w}$ diecezji tarnowskiej wyraziła się w podejmowaniu różnych inicjatyw, działań i form pomocy rodzinie (1) oraz w prowadzonej szczególnie intensywnie posłudze nauczania (2). Na tym polu dał się poznać jako mądry i przewidujący duszpasterz oraz chętnie słuchany kaznodzieja.

\section{Formy i działania podejmowane na rzecz małżeństw i rodzin}

W pewnym sensie nowy etap działalności duszpasterskiej na rzecz małżeństwa i rodziny rozpoczął się 26 lutego 1962 roku, kiedy to papież Jan XXIII bullą Summo Numinis mianował Jerzego Ablewicza biskupem ordynariuszem diecezji tarnowskiej, następcą po zmarłym w 1959 roku biskupie Janie Stepie po trzyletniej administracji sprawowanej przez wikariusza kapitulnego, którym był biskup Karol Pękala ${ }^{2}$. Wydarzeniem, które wywarło decydujący wpływ na styl pełnienia posługi biskupa Ablewicza w diecezji tarnowskiej był niewątpliwie Sobór Watykański II. Został on odczytany przez pasterza Kościoła tarnowskiego jako przełomowy znak czasu. Biskup całkowicie otworzył się na przeżycie jego przebiegu i dorobku, a także umożliwił to swoim diecezjanom. Starannie wprowadzał w diecezji jego reformy.

1 Jan Paweł II, Adhort. apost. Familiaris consortio (1981), nr 73.

2 Por. T. Szczurek, Szkic życia Ks. Biskupa Jerzego Ablewicza, w: Archiwum Diecezji Tarnowskiej [dalej: ADT], Teczka: Akta personalne Biskupa Jerzego Ablewicza, mps, s. 4. 
Czynił to na płaszczyźnie trzech podstawowych zadań Kościoła: nauczania, uświęcania i rządzenia ${ }^{3}$.

Troska o małżeństwo i rodzinę stała się szczególnym przedmiotem działań duszpasterskich biskupa tarnowskiego. Było to związane między innymi z tym, że od 1956 roku trwała w naszym państwie dokładnie przygotowana przez władze komunistyczne akcja propagandowa wymierzona przeciwko małżeństwu i rodzinie; stopniowo nasilała się, a szczyt swój osiągnęła w latach 1960-1968. Polegała ona na: wyśmiewaniu wielodzietności, stałym manipulowaniu danymi statystycznymi o rzekomym przeludnieniu Polski, propagowaniu aborcji i środków antykoncepcyjnych, udowadnianiu obywatelom, że tylko zmniejszenie ludności Polski może jej zapewnić dobrobyt ${ }^{4}$.

Mając to na uwadze, biskup Ablewicz niezmordowanie podejmował liczne działania na rzecz ratowania rodziny. Były to: pomoc charytatywna świadczona poprzez Caritas, sieć poradnictwa rodzinnego i specjalistycznego, dobre przygotowanie do małżeństwa, pomoc świadczona przez ruchy religijne oraz troska o trzeźwość.

Zdając sobie sprawę z trudu macierzyństwa i ojcostwa, arcybiskup Ablewicz spieszył z solidarną pomocą każdej rodzinie, a szczególnie rodzinom wielodzietnym. Swą troskę o rodziny wielodzietne wyraził w kazaniu wygłoszonym podczas odpustu w uroczystość Świętej Rodziny w Tarnowie 12 stycznia 1969 roku: „Kościół nigdy nie zrezygnuje z oddawania czci wielodzietnej rodzinie [...], bo wielodzietna rodzina to największy skarb"5. W dalszej części kazania wyraził szczególne uznanie dla tych małżonków, którzy na podstawie wspólnej rozważnej decyzji przyjmują liczniejsze potomstwo ${ }^{6}$. Zależało mu przede wszystkim na: katolickim wychowaniu dzieci, dbałości o wzajemną miłość małżeńską, modlitwie rodzinnej, wspólnym świętowaniu Dnia Pańskiego.

W czasie swego biskupiego posługiwania bp Ablewicz wielokrotnie kierował apele i wezwania do kapłanów i wiernych o otoczenie szczególną troską duszpasterską rodziny wielodzietne, a także zaniedbane, ubogie, z osobami

3 Por. J. Dudziak, Przełomowe ćwierćwiecze posługiwania Bpa Jerzego Ablewicza w Kościele tarnowskim, "Tarnowskie Studia Teologiczne” 2 (1987), t. 10, s. 9.

4 Por. W. Szewczyk, Z dziejów duszpasterstwa rodzin, w: Bóg potrzebuje rodziny, rodzina potrzebuje Boga. Księga pamiątkowa ku uczczeniu 30-lecia biskupiej posługi ks. bpa Józefa Gucwy dla rodzin Diecezji Tarnowskiej, red. W. Szewczyk, Tarnów 2000, s.146-147.

5 J. Ablewicz, Kazanie wygłoszone podczas odpustu w parafii św. Rodziny (Tarnów - 12 I 1969), w: ADT, Kazania Biskupa Jerzego Ablewicza, Teczka 1962-1981, mps, s. 3.

6 Por. tamże, s. 4-5. 
niepełnosprawnymi. Z jego inicjatywy powstały w Tarnowie działające do dziś prężnie: Dom dla Bezdomnych Mężczyzn oraz Dom Samotnej Matki, co pozwoliło uratować życie wielu dzieciom, a matkom odnaleźć właściwą drogę 7 . Pomoc rodzinom znajdującym się w trudnych sytuacjach była zapewniona przez oddziały Caritas. Rozwiązana przez władze komunistyczne Caritas działała za pasterzowania arcybiskupa Ablewicza poprzez zorganizowane wspólnoty opiekunek rejonowych w parafiach. Pod koniec jego życia Caritas reaktywowano. Było to jedno $\mathrm{z}$ ostatnich wielkich dzieł biskupiego posługiwania w duchu ewangelicznego hasła: „umywać nogi”.

Za niezwykle ważny obszar działania bp Ablewicz uznał pomoc świadczoną internowanym i więzionym w 1981 roku i rodzinom internowanym. Nie miał najmniejszej wątpliwości, że należy rozmawiać z przedstawicielami ówczesnej władzy, gdy chodzi o interwencję w sprawie internowanych i pomoc dla nich oraz ich rodzin. Był głęboko przekonany, że za wszelką cenę - oczywiście bez fałszywego kompromisu, który łatwo może się przerodzić w kompromitację - trzeba zrobić wszystko, by ulżyć tym, którzy znajdują się $\mathrm{w}$ trudnych warunkach. Mieli oni bowiem poczucie, że są niewinni, gdyż starali się coś zrobić dla wspólnej sprawy krzywdzonych i wyzyskiwanych, a zostali potraktowani jak przestępcy.

Ważne było także, aby zatroszczyć się o ich rodziny, które znalazły się $\mathrm{w}$ trudnej sytuacji. Zamknięci w więzieniu $\mathrm{z}$ niepokojem myśleli o najbliższych i przynosił im uspokojenie fakt, że Kościół troszczy się o ich rodziny. Biskup Ablewicz nie szczędził nigdy pieniędzy na tę pomoc, a ci, którzy zajmowali się internowanymi i ich rodzinami, mogli zawsze liczyć na życzliwie przyjęcie, wysłuchanie i wsparcie. Biskup wprost mówił, że zawsze, ilekroć będą potrzebne pieniądze, należy po nie przychodzić, a z pewnością się znajdą. Jeden z najbliższych współpracowników pasterza diecezji tarnowskiej ks. Michała Bednarz tak wspomina to wydarzenie:

Gdy na dzień 1 stycznia 1982 roku przygotowywany był pierwszy wyjazd do więzienia w Załężu, gdzie przebywali internowani z naszych terenów,

7 Por. P. Gajda, Troska arcybiskupa Jerzego Ablewicza o zorganizowanie i przeprowadzenie IV Synodu Diecezji Tarnowskiej (1982-1986), w: Świadek wierny. Dziesiąta rocznica śmierci arcybiskupa Jerzego Ablewicza, red. J. Stala, Tarnów 2000, s. 243.

8 Por. J. Gucwa, Służyć Kościołowi, w: Świadek wierny..., dz. cyt., s. 332. Por. także: W. Kostrzewa, Biskup wielkiego ducha, w: Świadek wierny..., dz. cyt., s. 418. 
Ksiądz Biskup zastrzegł sobie, że weźmie osobiście udział w tych odwiedzinach. Spędził w więzieniu cały dzień. Czym była ta wizyta dla uwięzionych - tylko oni sami mogliby powiedzieć. Oni wiedzą, ile wtedy uczynił dla pokrzywdzonych [...]. Tam, w murach więzienia, byli także przestępcy, gdyż dla pognębienia internowanych umieszczano ich w tych samych celach. Ksiądz Biskup nie dzielił wtedy ludzi. Niósł pomoc zarówno internowanym, jak i przestępcom. Nikt w tym wypadku nie czuł się pokrzywdzony czy pominięty przez Niego'

Tak było przez cały okres stanu wojennego. Interwencje przynosiły pewien skutek. Władze liczyły się z biskupem, chociaż to wcale nie znaczy, że kierowały się szacunkiem wobec władzy kościelnej. Było w tym pewne wyrachowanie. Interwencje biskupa bardzo często były skuteczne i niektórzy, zwłaszcza bardzo chorzy, mogli opuścić mury więzienia. Prawdą jest, że wszyscy wyszliby stamtąd wcześniej czy później i bez interwencji. Ale wiemy o tym dopiero teraz, a wtedy dla internowanych i ich rodzin ważny był każdy dzień, gdyż bardzo niepokoili się o najbliższych. Dlatego biskup ordynariusz nie wahał się nigdy i od pierwszych dni podpisywał petycje w ich sprawie ${ }^{10}$.

Wielkim dziełem arcybiskupa Ablewicza było zbudowanie struktur poradnictwa rodzinnego w ramach Diecezjalnego Duszpasterstwa Rodzin. Formacja rodziców, ratowanie ich przed świadomą laicyzacją i demoralizacją, otwarcie się na życie, troska o świętość małżeństw, chrześcijańskie wychowanie, właściwe podejście do sfery współżycia była możliwa dzięki powołaniu poradni rodzinnych ${ }^{11}$. Była to odpowiedź na naukę Soboru, która stawała się przeciwwagą dla polityki państwa zmierzającej do ograniczenia dzietności poprzez lansowanie przerywania ciąży i antykoncepcji. Już w 1964 roku pasterz diecezji zorganizował stałe formy szkolenia świeckich do pracy w poradniach rodzinnych. Tego rodzaju szkolenie w 1980 roku przybrało postać Studium Rodziny, które do dziś cieszy się wspaniałymi wynikami swojej działalności i czyni wiele dobrego, służąc pomocą narzeczonym, małżonkom, rodzinom ${ }^{12}$.

9 M. Bednarz, E. Łomnicki, Troska o uwięzionych i ich rodziny, w: Świadek wierny..., dz. cyt., s. 346.

10 Por. M. Bednarz, E. Łomnicki, Troska o uwięzionych i ich rodziny, dz. cyt., s. 346.

11 Por. W. Szewczyk, Z dziejów duszpasterstwa rodzin..., dz. cyt., s. 149-151.

12 Por. W. Kostrzewa, Biskup wielkiego ducha, w: Świadek wierny..., dz. cyt., s. 418. Por. także: E. Zięba, Był jak ojciec, w: Świadek wierny..., dz. cyt., s. 501-502. 
Obok poradni rodzinnych, będąc jakby ich przedłużeniem, przy Diecezjalnym Duszpasterstwie Rodzin działa od 1981 roku Poradnia Specjalistyczna i Telefon Zaufania - ARKA, która zatrudnia psychologów, pedagogów, duszpasterzy, lekarzy, prawników i służy pomocą nie tylko rodzinie, ale każdemu, kto potrzebuje pomocy i wsparcia ${ }^{13}$. Na tym polu szczególnie zasłużył się mianowany przez biskupa Ablewicza w 1981 roku prezes ARKI ks. Władysław Szewczyk, w tamtym czasie diecezjalny duszpasterz rodzin.

Troska biskupa Ablewicza o właściwą formację małżeństw i rodzin wyrażała się także poprzez organizację dwutygodniowych wakacyjnych oaz rodzinnych oraz kręgów rodzin katolickich, które były zakładane w parafiach przez te małżeństwa, które przeszły przez trzy stopnie wakacyjnych oaz. Celem oaz i kręgów było pogłębienie wiedzy religijnej i życia duchowego małżeństw i rodzin oraz przygotowanie do różnych form apostolstwa w parafiach i rodzinach. Każdy turnus oazowy prowadził ksiądz-moderator. Pomagali mu klerycy, którzy prowadzili spotkania biblijne, siostra zakonna, która pilnowała dzieci, oraz małżeńska para animatorska. Biskup tarnowski mianował też dekanalnych duszpasterzy odpowiedzialnych za formację małżeństw i rodzin. Pomocą służyły im wydawane corocznie od lat 70. stosowne materiały dla duszpasterstwa rodzin ${ }^{14}$.

Posługa duszpasterska arcybiskupa Ablewicza w diecezji, w tym duszpasterstwo małżeństw i rodzin, w dużej mierze realizowana było według wskazań wypracowanych na IV Synodzie Diecezji Tarnowskiej. Zgodnie z zaleceniami tegoż Synodu wszystkie parafie obowiązane były prowadzić systematyczne przygotowanie do małżeństwa w formie tzw. kursu przedmałżeńskiego. Częstotliwość kursu zależała od wielkości parafii. Program kursu obejmował ok. 30 tematów w pięciu blokach tematycznych. Wyrazem troski bpa Ablewicza o małżeństwa i rodziny były też systematycznie prowadzone dla nich w parafiach nabożeństwa stanowe, tridua, konferencje dla w ramach rekolekcji i odpustów ${ }^{15}$.

Wśród wielu problemów, które znalazły się centrum uwagi arcybiskupa Ablewicza, była też troska o trzeźwość w rodzinach. Arcybiskup miał świadomość, że troska o trzeźwość jest troską o rodzinę. W tym zakresie

13 Por. W. Szewczyk, Formy działań Kościoła w Tarnowie dla rodzin, w: Raport o stanie rodziny w Tarnowie, red. F. Adamski, H. Noga, B. Kurdybacha, Tarnów 1997, s. 178.

14 Por. W. Szewczyk, Z dziejów duszpasterstwa rodzin..., dz. cyt., s. 149-152.

15 Por. W. Szewczyk, Formy działań Kościoła w Tarnowie dla rodzin.., dz. cyt., s. 177-178. 
kontynuował dzieło swoich poprzedników. Każdego roku mocno angażował się w organizację w miesiącu wrześniu diecezjalnej pielgrzymki Apostolatu Trzeźwości do Szczepanowa i Odporyszowa. Głównym celem tych pielgrzymek było podjęcie zobowiązań abstynenckich oraz ekspiacja za zło w rodzinach spowodowane przez alkoholizm ${ }^{16}$. $Z$ tej okazji wydawał też listy i odezwy, poprzez które kształtował świadomość abstynencką. Z jego inicjatywy powstało Koło Świętego Stanisława, które poprzez odpowiednio przygotowanych świeckich pomagało $\mathrm{w}$ walce $\mathrm{z}$ nałogiem pijaństwa ${ }^{17}$. Troska o rodziny uzależnione od alkoholu wyrażała się również w promowaniu klubów AA i opiece duszpasterskiej nad nimi. Czuwało nad tym Diecezjalne Duszpasterstwo Trzeźwości ${ }^{18}$. Co roku w domu biskupim pasterz diecezji spotykał się z dekanalnymi duszpasterzami trzeźwości. Z uwagą słuchał ich wypowiedzi i poszukiwał nowych sposobów owocnej pracy na rzecz apostolatu trzeźwości. ${ }^{19}$

Należy podkreślić, że w realizowaniu wszelkich inicjatyw prorodzinnych bardzo skutecznie i z wielkim zaangażowaniem wspierał swojego ordynariusza biskup pomocniczy Józef Gucwa, któremu ten dział duszpasterstwa od 1969 roku podlegał ${ }^{20}$.

\section{Nauczanie pasterskie o małżeństwie i rodzinie}

Realizując swoją biskupią posługę, Jerzy Ablewicz na różne sposoby zabiegał o lepszy kształt życia religijno-moralnego małżeństwa i rodziny. Czynił to również poprzez kazania, listy pasterskie, głoszone rekolekcje, odezwy, programy duszpasterskie, $w$ których ciągle podkreślał potrzebę kształtowania życia małżeńskiego i rodzinnego w oparciu o naukę Jezusa Chrystusa.

Trwające dziesiątki lat w rzeczywistości polskiej laicyzacja i ateizacja, prowadzone za pomocą różnorakich środków i metod najmocniej, odbiły się na kondycji moralnej małżeństw i rodzin. Alarmująco brzmią słowa Ablewicza z kazania wygłoszonego do kobiet w Tarnowie w 1965 rokustwierdzające,

\footnotetext{
16 Por. W. Szewczyk, Formy działań Kościoła w Tarnowie dla rodzin.., dz. cyt., s. 179.

17 Por. W. Kostrzewa, Biskup wielkiego ducha, w: Świadek wierny..., dz. cyt., s. 418.

18 Por. W. Szewczyk, Formy działań Kościoła w Tarnowie dla rodzin..., dz. cyt., s. 179.

19 Por. W. Kostrzewa, Biskup wielkiego ducha, w: Świadek wierny..., dz. cyt., s. 419.

20 Por. Por. W. Szewczyk, Z dziejów duszpasterstwa rodzin..., dz. cyt., s. 150.
} 
że „małżeństwa i rodziny ogarnia coraz mocniej fala demoralizacji i rozbicia"21. Wypowiedź ta wskazuje na bezpośrednie przyczyny tego procesu. Według biskupa jest to spowodowane bezpośrednim kryzysem moralnym społeczeństwa, który był skutkiem działań laicyzujących, wiążących się z osłabieniem wiary i wartości moralnych.

Biskup świadom wszystkich zagrożeń, w których obliczu stanęły małżeństwo i rodzina, prowadził poprzez swoje kazania i listy pasterskie katechezę, mającą na celu ukazanie chrześcijańskiej koncepcji tych wspólnot. Podkreślał przy tym zasadniczą odmienność laickich wizji małżeństwa i rodziny.

Poważnym przejawem laicyzacji w odniesieniu do instytucji małżeństwa było szerzenie się przeświadczenia o dopuszczalności rozwodu, jak i faktyczny rozpad wielu ważnie zawartych małżeństw. Pasterz Kościoła tarnowskiego podniósł ten ważny problem życia społecznego między innymi podczas uroczystości poświęcenia kamienia węgielnego w Żarówce. Przyznał wtedy z wielkim bólem: „Jest źle, a nawet bardzo źle w naszym życiu małżeńskim i rodzinnym, gdyż niejednokrotnie ulega to życie rozbiciu. Małżonkowie i rodzice nie umieli i nie umieją panować nad sobą"22. Szczególnie mocno biskup krytykował liberalne prawo rozwodowe ${ }^{23}$.

Wbrew pesymizmowi i egoizmowi świata bp Ablewicz wraz z całym Kościołem wyraźnie opowiadał się za życiem. W liście pasterskim na Wielki Post w 1979 roku poświęconym Deklaracji Praw Dziecka Biskup pisał: „W świetle nauki Chrystusa, aby dać dziecku to, co najlepsze, trzeba przede wszystkim pozwolić mu ujrzeć światło dzienne, pozwolić mu żyć. Życie ludzkie jest wspaniałym darem Boga, do którego człowiek posiada niezaprzeczalne prawo od łona swej matki”24. Trzeba podkreślić, że bp Ablewicz piętnował jako ciężką obrazę godności człowieka wszelkie poczynania, które zmierzają

21 J. Ablewicz, Nauka rekolekcyjna wygłoszona do niewiast w katedrze tarnowskiej (Tarnów -1965), w: ADT, Kazania Biskupa Jerzego Ablewicza, Teczka 1962-1981, mps, s. 10.

22 J. Ablewicz, Przemówienie wygłoszone podczas poświęcenia kamienia węgielnego (Żarówka 1 V 1983), w: ADT, Kazania Biskupa Jerzego Ablewicza, Teczka 198 1-1983, mps, s. 6. Por. Tenże, Nauka rekolekcyjna wygłoszona do niewiast w katedrze tarnowskiej (Tarnów - 1965)..., s. 10.

23 W ostatnich latach - mówił Ablewicz w katedrze do uczestników kursu przedmałżeńskiego szczególnie raz po raz w naszych sądach odbywaja się przykre procesy rozwodowe. To jest wielki kryzys małżeństwa i rodziny. Tenże, Przemówienie wygłoszone w katedrze na zakończenie kursu przedmatżeńskiego (Tarnów - 1967), w: ADT, Kazania Biskupa Jerzego Ablewicza, Teczka 196 2-1981, mps, s. 2.

24 J. Ablewicz, Chrystusowa Deklaracja Praw Dziecka Bożego. List pasterski na Wielki Post (Tarnów11 I/ 1979), w: Tenże, Kościołowi napisz. Listy, odezwy, modlitwy okolicznościowe 196 2-1989, red. A. Kokoszka, A. Paciorek, Katowice 1991, s. 309. 
do ograniczenia w jakikolwiek sposób wolności małżonków w podejmowaniu decyzji co do potomstwa. W związku z tym domagał się zwłaszcza odrzucenia antykoncepcji ${ }^{25}$. Wyraźnie sprzeciwiał się też sterylizacji, praktykom spędzania płodu oraz manipulacjom genetycznym, które stanowią interwencję w Boży plan życia ${ }^{26}$. Szerzenie takich postaw oznacza fundamentalne zagrożenie kultury duchowej i moralnej narodu. Stąd też pasterz ostrzegał: „Pamiętajmy i weźmy sobie do serca, że grób nienarodzonych dzieci to jest grób kultury narodu [...]. Ten grób i nam grozi. Trzeba w ten grób odważnie popatrzeć"27.

Arcybiskup Ablewicz mówił też dużo o dobrym wychowaniu. Wiedział bowiem, że przy szerzącym się zepsuciu moralnym środowiska jest ono jedynym środkiem ocalenia człowieka. Odpowiedzialność za wychowanie spoczywa głównie na rodzicach. To oni, jak mówił w jednej z parafii, „mają być dla swoich dzieci chlebem i solą. Chlebem, który daje życie, i solą, która chroni od zepsucia" 28 . W rodzinie dzieci mają nauczyć się wybierać dobro, a odrzucać zło, stale wybierać styl życia zgodny z przykazaniami Bożymi. Zadanie wychowawcze rodziców jest zatem tak wielkiej wagi, że w wypadku, gdyby go nie spełniali, z trudnością można by ich było zastąpić.

Bp Ablewicz w swoim nauczaniu wskazywał również na udział rodziny we wspólnocie eklezjalnej. Podkreślał, że z jednaj strony Kościół buduje i wychowuje rodzinę chrześcijańską, z drugiej zaś, rodzina powinna być żywo obecna w całokształcie życia ludu Bożego i uczestniczyć w jego posłannictwie. Wspólnota rodzinna warunkuje też właściwy rozwój i trwanie społeczeństwa. „W rodzinie i dzięki niej - mówił Ablewicz podczas rekolekcji

25 Por. J. Ablewicz, Kazanie wygłoszone podczas Mszy św. dla Duszpasterstwa Rodzin (Tarnów 11 ( 1981), w: ADT, Kazania Biskupa Jerzego Ablewicza, Teczka 196 2-1981, mps, s. 1; Tenże, Kazanie wygłoszone w czasie poświęcenia kamienia węgielnego (Ostrowy Szlacheckie - 30 VIII 1981), w: ADT, Kazania Biskupa Jerzego Ablewicza, Teczka 196 2-1981, mps, s. 2.

26 Por. J. Ablewicz, Kazanie wygłoszone podczas poświęcenia plebanii (Lipinki - 3 // 1980), w: ADT, Kazania Biskupa Jerzego Ablewicza, Teczka 196 2-1981, mps, s. 4; Tenże, Przemówienie wygłoszone do uczniów szkoły organistowskiej (Tarnów - 27 V1981), w: ADT, Kazania Biskupa Jerzego Ablewicza, Teczka 196 2-1981, mps, s. 4; Tenże, Kazanie wygłoszone w czasie poświęcenia kamienia węgielnego (Ostrowy Szlacheckie - 30 VIII 1981)..., s. 2.

27 J. Ablewicz, Kazanie wygłoszone w czasie poświęcenia kamienia węgielnego (Ostrowy Szlacheckie - 30 VIII 1981)..., s. 3.

28 Por. J. Ablewicz, Kazanie wygłoszone podczas wizytacji (Uszew - 1965), w: ADT, Kazania Biskupa Jerzego Ablewicza, Teczka 196 2-1981, mps, s. 1. Por. Tenże, Trzecie kazanie wygłoszone podczas wizytacji kanonicznej (Brzesko - 14 VI 1965), w: ADT, Kazania Biskupa Jerzego Ablewicza, Teczka 196 2-1981, mps, s. 6. 
watykańskich - człowiek rozwija swoją naturę społeczną, uczy się żyć z drugimi i dla drugich"29. Rodzina jest pierwszą i niezastąpioną szkołą życia społecznego. Ale nie tylko rodzina, jak zauważył Biskup, jest na służbie społeczeństwa, także społeczeństwo ma obowiązek spieszyć z pomocą rodzinie. Społeczeństwo i państwo mają obowiązek stworzyć rodzinie warunki odpowiedniej egzystencji i realizacji jej zadań.

\section{Zakończenie}

Arcybiskup Jerzy Ablewicz w swoim duszpasterstwie i nauczaniu zawsze mocno akcentował ponadczasowe i praktyczne znaczenie swego posłannictwa, które wypływało z ewangelizacyjnej misji Kościoła. Jego służba i nauczanie, naznaczone wielkim pietyzmem dla wielowiekowego depozytu wiary, może stanowić wspaniały wzór klarownego wyrażania chrześcijańskich zasad moralnych, będących adekwatną odpowiedzią na te problemy, które niosą ze sobą małżeństwo i rodzina.

Wydaje się też, że przykład pasterza tarnowskiego, jego gorliwa posługa i cenne wypowiedzi mogą stać się pomocne dla małżeństw i rodzin; ich wartość tkwi także w jasnym sprecyzowaniu celu i sensu życia i ustaleniu właściwej postawy moralnej współczesnych, często zagubionych Polaków. Trzeba tylko chcieć zapoznać się z jego życiem i nauczaniem. Należy więc mieć nadzieję, że przedłożone refleksje staną się zaproszeniem do pogłębionego studium omówionych zagadnień, a przez to ukażą, jak wielkie i ważne zadania stoją wciąż przed współczesną rodziną polską.

29 J. Ablewicz, „Będziecie moimi świadkami”. Rekolekcje watykańskie (Wielki Post, 8-14 /I 1981), Paris 1983, s. 235. 